\title{
Assessment of drudgery level of female farm workers involved in sugarcane cultivation
}

\section{PRAGYA OJHA, POONAM SINGH AND ABHA SINGH}

Received: 24.02.2017; Revised: 24.04.2017; Accepted: 11.05.2017

See end of the paper for authors' affiliations

\section{PRAGYA OJHA}

Department of Family Resource Management, College of Home Science,

N.D. University of Agriculture and

Technology, Kumarganj, FAIZABAD (U.P.) INDIA

Email : ojha.pragya063@gmail.

com
ABSTRACT : Women's participation in sugarcane cultivation shows much heterogeneity at the regional level. Evidence suggests that women are often paid less than men, for the same work. Sugarcane cultivation is tedious, tiresome and labour consuming, because agricultural workers has to stand in field and bend for hours for performing the activities. Keeping this in view, the present study was planned to assess the rate of human drudgery female farm workers, during various phases of sugarcane cultivation. Results revealed that the weeding activity require maximum time ( $193.65 \mathrm{~min} /$ day) followed by harvesting activity requiring $162.79 \mathrm{~min} /$ day. In trash mulching activity, agricultural workers spend their maximum time i.e. $170.64 \mathrm{~min} / \mathrm{day}$. During cleaning of field activity, for agricultural workers required only $159.35 \mathrm{~min} / \mathrm{day}$. It was also observed that as compared with others, weeding was the maximum drudgery prone sugarcane cultivation activity based on drudgery index.

KEY WORDS: Drudgery, Agriculture workers, Sugarcane cultivation, Occupational hazards

- HOW TO CITE THIS PAPER : Ojha, Pragya, Singh, Poonam and Singh, Abha (2017). Assessment of drudgery level of female farm workers involved in sugarcane cultivation. Asian J. Home Sci., 12 (1) : 205207, DOI: 10.15740/HAS/AJHS/12.1/205-207. 